\title{
Graduate Writing Assignments Across Faculties in a Canadian University
}

\author{
Ling Shi \& Yanning Dong \\ University of British Columbia
}

\begin{abstract}
This study examines 143 graduate assignments across 12 faculties or schools in a Canadian university in order to identify types of writing tasks. Based on the descriptions provided by the instructors, we identified nine types of assignments, with scholarly essay being the most common, followed by summary and response, literature review, project, review, case analysis, proposal, exam, and creative writing. Many assignments are instructor-controlled and have specific content requirements. Some are also process-oriented, providing students with teacher or peer feedback on outlines or initial drafts, suggestions for topic choices, and examples of good writing. With an overview of the types of writing tasks across campus, the study has implications for English for Academic Purposes (EAP) or graduate writing program designers, material developers, educators working within and across disciplines, and researchers interested in the types of university writing assignments in Canada.
\end{abstract}

\section{Résumé}

Afin de relever les différentes tâches de rédaction exigées par l'une ou l'autre des 12 facultés ou écoles d'une université canadienne en particulier, cette étude analyse 143 travaux à faire par des étudiants. En se fondant sur les descriptions fournies par les chargés de cours, nous avons identifié huit types de travaux différents. Ainsi, l'essai scientifique était le type de rédaction le plus commun, venaient ensuite les autres types: le résumé de commentaires avec réponse à ceux-ci, la recension des écrits, l'examen de projets, l'étude de cas, la proposition, l'examen, et l'écriture créative. Bien des travaux sont dirigés par des instructeurs qui exigent un contenu précis. D’autres suivent un processus par lequel les étudiants reçoivent de leurs instructeurs ou de leurs 
pairs une rétroaction sur le plan fourni ou sur la première version du travail, ou encore des suggestions de sujets et des exemples de bonne rédaction. Avec son aperçu des types de tâches d'écriture requises sur le campus, cette étude a des répercussions sur le programme d'apprentissage de l'anglais à des fins académiques (English for Academic Purposes ou EAP) ou sur la conception de programmes d'écriture pour les étudiants de deuxième ou de troisième cycle, les créateurs de matériel, les éducateurs travaillant dans leur domaine ou de façon interdisciplinaire, de même que les chercheurs intéressés par les types de travaux d'écriture requis par les universités canadiennes.

Writing skills have been rated important in graduate education (Bridgeman \& Carlson, 1984). To contextualize the present study, we reviewed previous studies that explored the particularities and types of university writing assignments. Among these studies, we identified a group of surveys that classified large quantities of cross-discipline writing tasks based on assignment handouts, course syllabi, and/or student writing samples. These studies contribute to our knowledge of a larger picture of university writing assignments compared to studies of university writing based on ethnographic research (e.g., Prior, 1998), writing tasks in a specific discipline like business (Canseco \& Byrd, 1989; Zhu, 2004), or a questionnaire survey among faculty members (e.g., Bridgeman \& Carlson, 1984). However, only one of the large-scale surveys explored graduate writing tasks across disciplines (Cooper \& Bikowski, 2007); the rest all focused on undergraduate (Braine, 1989; Horowitz, 1986) or both graduate and undergraduate writing (Gardener \& Nesi, 2013; Hale, Taylor, Bridgeman, Carson, Kroll, \& Kantor, 1996; Melzer, 2009; Moore \& Morton, 2005). Those focused on either undergraduate or graduate writing were studies of single institutions in the US, whereas those which explored both undergraduate and graduate writing were national studies involving multiple institutions in Australia (Moore \& Morton, 2005), Britain (Gardner \& Nesi, 2013), the US (Melzer, 2009), and the US and Canada (Hale et al., 1996). Following Cooper and Bikowski (2007), who stress the importance of investigating graduate courses across disciplines, this study analyzes and compares 143 graduate assignments based on handouts or course syllabi across 12 faculties or schools in a Canadian university. The purpose is to fill in the gap in survey studies on graduate writing tasks in order to generate information for EAP writing programs, which help students with graduate writing, and researchers interested in the types of graduate writing assignments.

\section{Previous Classifications of University Writing Assignments}

\section{Undergraduate Writing Tasks}

In previous research on classifications of university writing assignments, two influential studies focused on undergraduate writing tasks: Horowitz (1986) examined 54 writing assignments from 29 courses ( 28 undergraduate and one graduate) in 17 departments in a US university, whereas Braine (1989), in another US university, examined 61 nonexamination writing tasks from ten undergraduate science and technology courses, as well as student papers written in response to each type of assignment. Horowitz's data introduced seven categories of writing tasks: 
- summary of/reaction to a reading

- annotated bibliography

- report on a specified participatory experience

- connection of theory and data

- case study

- synthesis of multiple sources

- research project

Among these categories, synthesis of multiple sources $(15=28 \%)$ was the most frequently assigned. Of the 54 assignments, 35 required students to find, organize, and present data according to fairly explicit instructions. Following Horowitz's taxonomy of writing tasks, Braine analyzed his data and added a new category: report on a simulated participatory experience, which required no activity to obtain data. Most of the writing tasks (52 out of 61), such as lab or technical reports, fit into the category of report on a specified participatory experience. Many of these tasks also specified an audience beyond the classroom. Because of the large proportion of such writing tasks, Braine indicated the necessity of making a close examination of the skills required in completing such writing tasks. Due to a focus on undergraduate courses in both studies, it is important to find out if the relevant findings apply to graduate courses.

\section{Graduate Writing Tasks}

With a focus on graduate assignments to inform the needs of international students at a large American university, Cooper and Bikowski (2007) analyzed 200 course syllabi from 20 departments with high international student enrollment, including electrical engineering, international studies, physics, and educational studies, and did follow-up interviews to help categorize ambiguous assignments. Some of the writing tasks identified (e.g., library research paper, report on an experiment/project, summary/abstract, article/book review, and annotated bibliography essay) were similar to those undergraduate writing tasks identified by Horowitz (1986) and Braine (1989); other tasks such as essay, journal article, plan/proposal, case study, and unstructured writing might be more pertinent to graduate writing since they were not reported by Horowitz and Braine, who focused on undergraduate writing. The study revealed that library research papers and project reports (18\%) were more frequently assigned graduate writing tasks in the participating university. Social science, arts, and humanities courses were also found to have a greater number and a wider variety of assigned writing tasks (e.g., reviews, plans/proposals, case studies, and summaries/abstracts) than science, math, and engineering courses. With only one study focusing on graduate writing, more research is needed to explore writing assignments at the graduate level.

\section{Studies Involving Both Graduate and Undergraduate Writing Tasks}

Several studies examining writing tasks in both graduate and undergraduate courses were conducted at the national level across multiple institutions. Among them, Hale et al. (1996) studied 162 courses from eight universities in the US and Canada to inform the development of the TOEFL test (Test of English as a Foreign Language), whereas Moore and Morton (2004) examined 79 courses in two Australian universities to help 
develop the IELTS test (International English Language Testing System). The two studies identified similar tasks found in Horowitz (1986), such as case study, summary, literature review or synthesis of multiple sources, and research report or report on a specified participatory experience. Some additional tasks identified include essay, plan/proposal, review or book review (Hale et al.; Moore \& Morton), documented computer program (Hale et al.), exercise, and short answer (Moore \& Morton). Both studies found essay the most common genre for business students. Hale et al. indicated that writing tasks that require greater length demand more cognitive skills such as application, analysis, synthesis, and evaluation. Hale et al. also found that library research paper or literature review was more frequently assigned in graduate courses than undergraduate courses (39\% vs. 9\% respectively), especially in physical/mathematical science and engineering disciplines when compared with the social science disciplines (58\% vs. $26 \%$ respectively). Moore and Morton, although they did not illustrate any differences between graduate and undergraduate levels, reported that almost all the tasks involved the use of either primary or/and secondary sources/references. Since only five graduate disciplines were involved in Hale et al. and less than half of the tasks represented graduate writing in Moore and Morton, the findings fall short in representing writing requirements at the graduate level.

Focusing on both graduate and undergraduate levels on a much larger scale, Gardner and Nesi (2013) classified 2761 writing samples based on the British Academic Written English (BAWE) corpus across disciplines (arts and humanities, life sciences, physical sciences, and social sciences) in four British universities, and Melzer (2009) conducted a national study of 2100 writing assignments from 400 courses across disciplines (natural and applied sciences, social sciences, business, and arts and humanities) in 100 US postsecondary institutions. Gardner and Nesi identified 13 types of assignments:

- case study

- critique

- design specification

- empathy writing

- essay

- exercise

- explanation

- literature survey

- methodology recount

- narrative recount

- problem question

- proposal

- research report

Gardner and Nesi found essay to be the most popular type of assignment (43\%), followed by methodology recount (13\%). In addition, essay was more frequently assigned to students in arts and humanities (83\%) and social sciences (56\%), whereas methodology recount was much more frequently assigned to students in life sciences (22\%) and physical sciences (27\%). Similarly, Melzer reported an extensive list of genres, most of which have been identified by previous researchers. The majority of the tasks were informative (66\%) and persuasive (17\%), with an emphasis on the examiner or instructor as the audience. Except the short-answer exams, which only required rote memorization and recall 
of facts, most of the other genres were content specific or, in Melzer's words, "tied so closely to discipline-specific ways of making meaning" (p. W257). Some instructors (50 out of 400) also responded to students' drafts during the writing process. As large scale studies, both studies contribute to our knowledge of more recent writing assignments at the national level in either England or the US.

The above review illustrates that research, while identifying some frequently used writing tasks, has generated slightly different classifications of writing tasks due to the levels of courses involved and the disciplines or contexts under study. It is important to note that large-scale surveys involving multiple institutions with thousands of writing tasks collected (Gardner \& Nesi, 2013; Melzer, 2009) allowed for greater generalizability than those studies of single institutions (Braine, 1989; Cooper \& Bikowski, 2007; Horowitz, 1986) or a small group of institutions (Hale et al., 1996; Moore \& Morton, 2004) with hundreds but not thousands of writing tasks collected. These studies, while contributing to our understanding of the various types of university writing assignments, have also indicated gaps for further studies. First of all, further research is needed to explore graduate writing tasks because only one study (Cooper \& Bikowski, 2007) has devoted particular effort to writing tasks across disciplines at the graduate level. Following Cooper and Bikowski, we aim to examine graduate writing assignments to help prepare students for academic excellence in their graduate programs. In addition, research is needed to explore cases in countries such as Canada since only one study has included data from Canadian universities (Hale et al., 1996). Although Garner and Nesi (2013) claim that the writing assignments they identified in British universities are applicable to all university contexts, we believe that it is necessary to explore the Canadian context because, as Braine (1989) has pointed out, writing tasks may mean different things in different contexts.

\section{Research Questions}

The present study, with data collected in a Canadian university, aligns with the research tradition of survey studies on university writing tasks by focusing not only on task types but also task requirements and guidelines. Such information is important and necessary for achieving a comprehensive understanding of the writing demands in disciplinary courses as well as informing writing instructions that can lead students to academic success in their graduate education. Building on the prior studies on university writing assignments, this study is guided by the following two questions:

1. What are the types of graduate writing tasks across faculties in the participating university?

2. What are the requirements and guidelines of these assignments?

\section{Method}

\section{Participants}

A total of 86 faculty members participated in the study in the academic year of 2011 and 2012. Initially, invitations were sent to faculty members listed on the university faculty website (about 2,000) asking for a typical writing assignment from a graduate course they were currently teaching. A total of 312 people responded, among which 86 attached details of the writing assignments in the form of a course handout or syllabus. Those who 
did not send the assignments explained that they were on leave $(n=70)$ or not currently teaching a graduate course $(n=46)$. Some also said they had either few writing assignments $(n=34)$ or nothing appropriate to contribute $(n=45)$.

The present study is based on the writing assignments received from 86 faculty members representing 12 faculties/schools. Over half of the faculty members $(51=59 \%)$ were full professors, followed by associate professors $(18=21 \%)$, assistant professors $(12=$ $14 \%)$, and instructors or lecturers $(5=6 \%)$. Table 1 summarizes the participants' profiles.

Table 1.

Participants' Profiles

\begin{tabular}{|c|c|c|c|c|c|c|c|c|}
\hline \multirow[t]{2}{*}{ Area } & \multirow[t]{2}{*}{ Faculty/School } & \multicolumn{2}{|c|}{ Gender } & \multicolumn{4}{|c|}{ Positions } & \multirow[t]{2}{*}{ Total } \\
\hline & & M & $\mathrm{F}$ & Prof. & $\begin{array}{l}\text { Assoc. } \\
\text { Prof. }\end{array}$ & $\begin{array}{c}\text { Assist. } \\
\text { Prof. }\end{array}$ & $\begin{array}{l}\text { Instructor / } \\
\text { Lecturer }\end{array}$ & \\
\hline \multirow{5}{*}{$\begin{array}{l}\text { Arts \& } \\
\text { Social Sci- } \\
\text { ences }\end{array}$} & Arts & 6 & 7 & 6 & 6 & 1 & $\mathrm{O}$ & 13 \\
\hline & Education & 10 & 8 & 10 & 3 & 3 & 2 & 18 \\
\hline & Business & 1 & 1 & 2 & $\mathrm{O}$ & $\mathrm{O}$ & $\mathrm{O}$ & 2 \\
\hline & Social Work & 1 & $\mathrm{O}$ & $\mathrm{O}$ & 1 & $\mathrm{O}$ & $\mathrm{O}$ & $\mathbf{1}$ \\
\hline & Library Studies & 1 & 4 & 2 & $\mathrm{O}$ & 2 & 1 & 5 \\
\hline \multirow{6}{*}{$\begin{array}{l}\text { Applied } \\
\text { Sciences \& } \\
\text { Sciences }\end{array}$} & Applied Science & 5 & 6 & 8 & 1 & 1 & 1 & 11 \\
\hline & Science & 4 & 3 & 5 & 1 & 1 & $\mathrm{O}$ & 7 \\
\hline & Medicine & 11 & 7 & 10 & 4 & 4 & $\mathrm{O}$ & 18 \\
\hline & $\begin{array}{l}\text { Pharmaceutical Sci- } \\
\text { ences }\end{array}$ & $\mathrm{O}$ & 4 & 1 & 2 & $\mathrm{O}$ & 1 & 4 \\
\hline & Forestry & 1 & $\mathrm{O}$ & 1 & $\mathrm{O}$ & $\mathrm{O}$ & $\mathrm{O}$ & $\mathbf{1}$ \\
\hline & Land \& Food System & 2 & 3 & 5 & $\mathrm{O}$ & $\mathrm{O}$ & $\mathrm{O}$ & 5 \\
\hline \multicolumn{2}{|c|}{ Interdisciplinary Studies } & 1 & $\mathrm{O}$ & 1 & $\mathrm{O}$ & $\mathrm{O}$ & $\mathrm{O}$ & $\mathbf{1}$ \\
\hline \multicolumn{2}{|l|}{ Total } & 43 & 43 & 51 & 18 & 12 & 5 & 86 \\
\hline \multicolumn{2}{|l|}{$\%$} & $50 \%$ & $50 \%$ & $59 \%$ & $\mathbf{2 1 \%}$ & $14 \%$ & $6 \%$ & $100 \%$ \\
\hline
\end{tabular}

\section{Assignments collected}

A total of 143 writing assignments from 90 graduate courses were collected from the 86 participating faculty members (Table 2). The description of the assignments totalled 54,863 words with an average of 383 words for each. The majority of participants $(n=58)$ each sent one writing assignment and the rest $(n=28)$ sent two or more. Most of the assignments were from the faculties of education $(36=25 \%)$, medicine $(25=17 \%)$, applied sciences $(22=15 \%)$, and arts $(20=14 \%)$. 
Table 2.

Faculties, Courses, Participating Instructors, and Assignments

\begin{tabular}{llrrrr}
\hline Area & Faculty/Schools & Participants & Courses & \multicolumn{2}{c}{ Assignments } \\
\cline { 5 - 6 } & & & & \multicolumn{1}{c}{ No. } & \multicolumn{1}{c}{$\%$} \\
\hline Arts \& Social Sciences & Arts & $\mathbf{1 3}$ & $\mathbf{1 4}$ & $\mathbf{2 0}$ & $\mathbf{1 4 \%}$ \\
& Education & $\mathbf{1 8}$ & $\mathbf{1 9}$ & $\mathbf{3 6}$ & $\mathbf{2 5 \%}$ \\
& Business & 2 & 2 & 3 & $2 \%$ \\
& Social Work & 1 & 1 & 2 & $1 \%$ \\
Applied Sciences \& Sciences & Library Studies & 5 & 5 & 5 & $3 \%$ \\
& Applied Science & $\mathbf{1 1}$ & $\mathbf{1 3}$ & $\mathbf{2 2}$ & $\mathbf{1 5 \%}$ \\
& Science & 7 & 7 & 10 & $7 \%$ \\
& Medicine & $\mathbf{1 8}$ & $\mathbf{1 8}$ & $\mathbf{2 5}$ & $\mathbf{1 7 \%}$ \\
& Pharmaceutical Sciences & 4 & 4 & 5 & $3 \%$ \\
Interdisciplinary Studies & Forestry & 1 & 1 & 2 & $1 \%$ \\
Total & Land and Food System & 5 & 5 & 10 & $7 \%$ \\
& & 1 & 1 & 3 & $2 \%$ \\
& & $\mathbf{8 6}$ & $\mathbf{9 0}$ & $\mathbf{1 4 3}$ & $\mathbf{1 0 0 \%}$ \\
\hline
\end{tabular}

\section{Coding of the Assignments}

The 143 assignments were first coded with four letters and two numbers: the first two letters indicate the faculty (e.g., AS = applied sciences), the next two letters indicate the department (e.g., $\mathrm{CB}=$ chemical and biological engineering), the first number indicates the course (as each course is numbered in every department in the present data), and the second number indicates the assignment (as the instructor of the same course might submit more than one assignment). For example, ASCB21 means applied sciences, chemical and biological engineering, Course 2 in the department, Assignment 1 of the course.

We then read the assignments repeatedly and classified them based on the descriptions and requirements provided. We also coded each assignment to indicate (a) weighting of the assignment in the final course grade; requirements for (b) length and (c) content; and whether it was process-oriented with (d) feedback during the writing process, (e) suggested topics, and (f) examples of good writing. To compare the length requirement, we recorded the minimum length when a range of length was specified. If the number of pages rather than words were mentioned for the required length, the total number of words was calculated based on an estimation of 200 words (double-spaced) or 400 words (single-spaced) per page. Double space was assumed unless single space was mentioned. Descriptive analyses were then conducted based on the coding to identify and compare the types of writing tasks and the relevant requirements and guidelines.

\section{Findings and Discussion}

\section{Types of Writing Assignments across Faculties}

We identified a total of nine types of writing assignments in the present data:

- literature review

- scholarly essay

- proposal 
- case analysis

- project

- review

- summary and response

- creative writing

- exam

The definitions of these assignments are based on the descriptions and requirements provided by the participating faculty members (Table 3). Since the terminology used to classify assignments varies from study to study and instructors may not always be explicit about the details of the genre they require, we took care when comparing these assignments and chose to use the terms that are frequently used in the assignment descriptions of the participating faculty members. Although both literature review and scholarly essay require library research, we distinguished the two in the present data because, while the former focuses on the state of knowledge and gaps in literature, the latter requires students to address a theoretical or methodological issue related to course content (See examples in Table 3).

With the exception of creative writing and exam, the assignments could be grouped into three major categories: (a) library research paper that requires searching and synthesizing multiple sources, (b) research paper that requires actual, simulated, or proposed participatory research experiences, and (c) evaluation and reflection of one's own or another's work. Table 4 illustrates that a total of 140 assignments (excluding the three from the interdisciplinary school) are from arts/social sciences $(n=66)$ and sciences/applied sciences $(n=74)$.

Table 4 illustrates that seven of the nine types of assignments (scholarly essay, summary and response, literature review, project, review, case analysis, and proposal) are more frequently used in the present data. Of the seven types of assignments, scholarly essay has the highest frequency $(29=21 \%)$, followed by summary and response ( $22=16 \%)$, literature review $(20=14 \%)$, and project $(20=14 \%)$. These assignments, which involve the use of source texts and research activities, add further support for previous findings that university writing is mostly based on research or use of data or source materials rather than personal opinions (Canseco \& Byrd, 1989; Horowitz, 1986; Moore \& Morton, 2004). It is interesting to note that, in the present data, scholarly essay is far more common in arts and social sciences than in science and applied science (22 vs. 7 respectively), whereas case analysis is far more common in applied sciences than in arts and social sciences (12 vs. 2 respectively). These differences reinforce the need to explore more disciplinary differences.

Since the majority of assignments (103 out of 143, Table 2) were collected from four faculties (arts, education, applied science and medicine), we compared the seven more frequently used types of assignments across the four faculties (Table 5). Several tendencies emerge based on the data collected. For example, students in applied sciences seem to write fewer proposals $(1=5 \%)$ and summary and responses $(1=5 \%)$, whereas arts students seem to write fewer project papers $(1=5 \%)$ than their peers in the other faculties. The present data also suggests that students in applied sciences write more literature reviews $(7=$ $32 \%$ ) than students in other faculties. In addition, there seem to be differences between the faculties of education and arts and the faculties of applied sciences and medicine. The former tend to assign more scholarly essays ( $13=37 \%$ and $5=26 \%$ respectively) than the latter ( $3=14 \%$ and $2=9 \%$ respectively), whereas the latter tend to write more case analyses ( $4=18 \%$ and $5=22 \%$ respectively) than the former ( $1=5 \%$ and o respectively). 
Table 3. Definitions and Examples of Nine Types of Assignments

\begin{tabular}{|c|c|c|}
\hline Types & Definitions & Examples (episodes from assignment description) \\
\hline $\begin{array}{l}\text { Literature } \\
\text { review }\end{array}$ & $\begin{array}{l}\text { Review the relevant liter- } \\
\text { ature to discuss the state } \\
\text { of knowledge or identify } \\
\text { gaps in research. }\end{array}$ & $\begin{array}{l}\text { Write a review of the literature on mass transfer with } \\
\text { multi-phase flow in three-dimensional electrodes. Your } \\
\text { answer should include some quantitative information } \\
\text { on mass transfer rates in these multi-phase systems. } \\
\text { (ASCB14) }\end{array}$ \\
\hline $\begin{array}{l}\text { Scholarly } \\
\text { essay }\end{array}$ & $\begin{array}{l}\text { Identify, synthesize, } \\
\text { and assess a theoreti- } \\
\text { cal or methodological } \\
\text { issue. Could include data } \\
\text { analysis. }\end{array}$ & $\begin{array}{l}\text { This assignment is to analyze a theoretical perspective } \\
\text { that guides and informs a strategy of qualitative in- } \\
\text { quiry. A theoretical perspective or lens can be selected } \\
\text { from critical theory, feminism, postcolonial theory, } \\
\text { indigenous perspectives, or symbolic interactionism. } \\
\text { (ASNU31) }\end{array}$ \\
\hline Proposal & $\begin{array}{l}\text { Describe what you are } \\
\text { interested in, why it is } \\
\text { worth studying, the con- } \\
\text { text, and ways you intend } \\
\text { to do the research. }\end{array}$ & $\begin{array}{l}\text { Develop a research proposal on a health services and } \\
\text { systems question that interests you. If you propose us- } \\
\text { ing a certain database, this database should exist and } \\
\text { be accessible. (MEPP31) }\end{array}$ \\
\hline Case analysis & Analyze a case scenario. & $\begin{array}{l}\text { Choose a policy document from your workplace and } \\
\text { analyze the policy as well as the responses to it from } \\
\text { internal and external interest groups. (EDES12) }\end{array}$ \\
\hline Project & $\begin{array}{l}\text { Report on a research } \\
\text { project or lab experiment } \\
\text { based on data collection/ } \\
\text { analysis. }\end{array}$ & $\begin{array}{l}\text { Create and implement a novel user interface either with } \\
\text { hardware, software, or both. You must also evaluate } \\
\text { it using experiments with users that follow the ethical } \\
\text { protocol for this course. (ASEC12) }\end{array}$ \\
\hline Review & $\begin{array}{l}\text { Review a book, article, } \\
\text { conference paper, film, } \\
\text { poem, or another stu- } \\
\text { dent's, or your own, } \\
\text { paper. }\end{array}$ & $\begin{array}{l}\text { Review the conference paper assigned. You should } \\
\text { include a summary of the paper, comment on the con- } \\
\text { tributions, rate [the paper], and recommend whether it } \\
\text { should be accepted or rejected. (ASEC11) }\end{array}$ \\
\hline $\begin{array}{l}\text { Summary \& } \\
\text { response }\end{array}$ & $\begin{array}{l}\text { Summarize and reflect on } \\
\text { what one has learnt. }\end{array}$ & $\begin{array}{l}\text { Prepare a brief summary [... .] of thoughts, impres- } \\
\text { sions, feelings, and questions that arose during the } \\
\text { course of the reading assignment. Include a brief com- } \\
\text { ment and analysis regarding the implications of the } \\
\text { above for your social work practice. (SWSW11) }\end{array}$ \\
\hline $\begin{array}{l}\text { Creative } \\
\text { writing }\end{array}$ & $\begin{array}{l}\text { Write original material. } \\
\text { Length, subject, and } \\
\text { treatment depend on the } \\
\text { content. }\end{array}$ & $\begin{array}{l}\text { Write a short story about whatever characters, plot, } \\
\text { theme, and setting you choose. (ARCW11) }\end{array}$ \\
\hline Exam & $\begin{array}{l}\text { Answer questions that } \\
\text { test comprehension and } \\
\text { integration of key con- } \\
\text { cepts/issues covered in } \\
\text { the course. }\end{array}$ & $\begin{array}{l}\text { How does the solid tumour microenvironment limit } \\
\text { therapeutic outcome after radiation therapy, chemo- } \\
\text { therapy, and surgery? Choose one of these standard } \\
\text { therapies and improve it. Design a therapeutic strategy } \\
\text { to counteract the detrimental effects of the tumour } \\
\text { microenvironment on the therapy you have chosen. Ex- } \\
\text { plain how your new therapeutic strategy will improve } \\
\text { the outcome. (MEPL11) }\end{array}$ \\
\hline
\end{tabular}


Table 4.

Summary of Assignments across Two Disciplinary Areas

\begin{tabular}{|c|c|c|c|c|c|}
\hline \multirow[t]{2}{*}{ Task types } & & \multirow[t]{2}{*}{ Arts \& Social Science } & \multirow{2}{*}{$\begin{array}{l}\text { Science \& Applied } \\
\text { Science }\end{array}$} & \multicolumn{2}{|c|}{ Total } \\
\hline & & & & No. & $\%$ \\
\hline \multirow{3}{*}{$\begin{array}{l}\text { Library } \\
\text { research }\end{array}$} & Literature review & 6 & 14 & 20 & $14 \%$ \\
\hline & Scholarly essay & 22 & 7 & 29 & $21 \%$ \\
\hline & Subtotal & & & 49 & $35 \%$ \\
\hline \multirow[t]{4}{*}{ Research } & Proposal & 4 & 9 & 13 & $9 \%$ \\
\hline & Case analysis & 2 & 12 & 14 & $10 \%$ \\
\hline & Project & 9 & 11 & 20 & $14 \%$ \\
\hline & Subtotal & & & 47 & $34 \%$ \\
\hline \multirow{3}{*}{$\begin{array}{l}\text { Evaluation \& } \\
\text { reflection }\end{array}$} & Review & 9 & 6 & 15 & $11 \%$ \\
\hline & Summary \& response & 11 & 11 & 22 & $16 \%$ \\
\hline & Subtotal & & & $\mathbf{3 7}$ & $26 \%$ \\
\hline \multirow[t]{3}{*}{ Other } & Creative writing & 1 & 1 & 2 & $1 \%$ \\
\hline & Exam & 2 & 3 & 5 & $4 \%$ \\
\hline & Subtotal & & & 7 & $5 \%$ \\
\hline Total & & $66(47 \%)$ & $74(53 \%)$ & 140 & $100 \%$ \\
\hline
\end{tabular}

Table 5 .

Seven Types of Assignments across Four Faculties

\begin{tabular}{lcrrrrrrrrr}
\hline & \multicolumn{2}{c}{ Arts } & \multicolumn{2}{c}{ Education } & \multicolumn{2}{c}{$\begin{array}{c}\text { Applied } \\
\text { Science }\end{array}$} & Medicine & \multicolumn{2}{c}{ Total } \\
& \multicolumn{1}{c}{} & \multicolumn{1}{c}{$\%$} & \multicolumn{1}{c}{ No. } & \multicolumn{1}{c}{$\%$} & \multicolumn{1}{c}{ No. } & \multicolumn{1}{c}{$\%$} & No. & \multicolumn{1}{c}{$\%$} & No. & $\%$ \\
\hline Literature review & 3 & $16 \%$ & 1 & $3 \%$ & 7 & $32 \%$ & 3 & $13 \%$ & $\mathbf{1 4}$ & $\mathbf{1 4 \%}$ \\
Scholarly essay & 5 & $26 \%$ & 13 & $37 \%$ & 3 & $14 \%$ & 2 & $9 \%$ & $\mathbf{2 3}$ & $\mathbf{2 3 \%}$ \\
Proposal & 2 & $11 \%$ & 2 & $6 \%$ & 1 & $5 \%$ & 4 & $17 \%$ & $\mathbf{9}$ & $\mathbf{9 \%}$ \\
Case analysis & 1 & $5 \%$ & 0 & $0 \%$ & 4 & $18 \%$ & 5 & $22 \%$ & $\mathbf{1 0}$ & $\mathbf{1 0 \%}$ \\
Project & 1 & $5 \%$ & 7 & $20 \%$ & 5 & $23 \%$ & 2 & $9 \%$ & $\mathbf{1 5}$ & $\mathbf{1 5 \%}$ \\
Review & 4 & $21 \%$ & 5 & $14 \%$ & 1 & $5 \%$ & 2 & $9 \%$ & $\mathbf{1 2}$ & $\mathbf{1 2 \%}$ \\
Summary \& Response & 3 & $16 \%$ & 7 & $20 \%$ & 1 & $5 \%$ & 5 & $22 \%$ & $\mathbf{1 6}$ & $\mathbf{1 6 \%}$ \\
Total (\%) & 19 & $100 \%$ & 35 & $100 \%$ & 22 & $100 \%$ & 23 & $100 \%$ & 99 & $100 \%$ \\
\hline
\end{tabular}

A close analysis of such tasks as scholarly essay and case analysis often require, as Melzer (2009) observed, "disciplinary-specific ways of making meaning" (p. W257). Both assignments tend to suggest audiences beyond the course instructor, including academic or professional audiences. For example, a scholarly essay in history/arts (ARHI13, Example 
1, Appendix) is used to teach students to write a historiographical essay for an academic audience in the discipline. As a typical scholarly essay assignment, it requires students to write a historiographical essay by critically reviewing literature, offering understanding of the context, and identifying theoretical and methodological influences. Other examples of a scholarly essay include an analytic paper "to examine the application of educational technologies in science and mathematics learning and teaching" (EDCP11), a history paper "to compare and contrast the understanding of planning history presented in two different contexts" (ASCR11), a theory paper to "theorize an application (artifact, device, or technique) related to Educational technology" (EDCP51), or to "analyze a theoretical perspective that guides and informs a strategy of qualitative inquiry" (ACNU31). The key is to engage students in scholarly communication and professional knowledge construction. Students are often explicitly asked to model the peer-reviewed scholarly article and to "engage the scholarship, present some new approach or thesis, and add to the profession" (AREN11, emphasis original).

Like the scholarly essay assignment, a case analysis also requires students to write for a professional audience in their field. For example, the case analysis in Family Practice/medicine (MEFP11, Example 2, Appendix) illustrates how the assignment is used to teach or train midwives through a medical scenario involving a professional audience. The case scenario contains detailed information of a medical dispute involving a newborn baby diagnosed with a paralyzed shoulder. Students were required to communicate with a legal representative and provide a rationale for the procedure they followed. While this scenario could be based on a true medical case, others are hypothetical. As an example, a case analysis in Population and Public Health (MEPP21, Example 3, Appendix) posited an environmental scenario about gas detection in tap-water samples. Although it refers to the name of a local town, the case "is entirely hypothetical." Like the case analysis in Family Practice, the environmental case scenario requires students to act professionally by preparing a short and long-term response to the situation and bidding for a contract to conduct an exposure assessment to determine the extent of the contamination, identify sources and factors affecting the presence of gasoline in the water supplies, and develop plans to control the exposure. By pushing students to apply textbook knowledge to a practical context, case analysis, as the above two examples illustrate, is a useful assignment for professional training. Students are instructed to write professionally for a professional audience. Since writing assignments are typically only read and marked by the course instructor, it is interesting to see how these graduate-level instructors present their students to a target audience beyond the classroom.

\section{Requirements and Guidance}

One requirement for many of these assignments is length. About half of the seven types of assignments $(n=69)$ indicate a specific required length, ranging from 100 to 12,000 words. As Table 6 shows, proposal has the longest length $(3,666)$, followed by project $(2,694)$, scholarly essay $(2,562)$, and literature review $(1,710)$. The other three, case analysis, review, and summary and response are all under 1,00o words. A close look at the proposal requirements reveals that the assignments are tied to the program requirements, such as a thesis proposal in zoology (SCZO11), a graduation design project proposal in architecture (ASAL11), a grant proposal in microbiology and immunology (SCMI12) and linguistics 
(ARLI12), or a project proposal in mathematics (SCMA12), so the length of the writing tasks is often in reference to the requirement of the program, not the course instructors. For example, students are instructed to follow the length and style of granting agencies for writing grant proposals (ARL112) and are required to submit their project proposals not only to the course instructor but also their supervisors (ASAL11). There is certainly a close relationship between writing tasks and program requirements at the graduate level.

Table 6.

Average Length of the Seven Types of Assignments

\begin{tabular}{lcc}
\hline Task types & $\begin{array}{c}\text { Average minimum length } \\
\text { (in words) }\end{array}$ & $\begin{array}{c}\text { No. of assignments with } \\
\text { length requirement }\end{array}$ \\
\hline Literature review & 1,710 & 10 \\
Scholarly essay & 2,562 & 16 \\
Proposal & 3,666 & 6 \\
Case analysis & 800 & 6 \\
Project & 2,694 & 9 \\
Review & 911 & 9 \\
Summary \& response & 761 & 13 \\
Total & & 69 \\
\hline
\end{tabular}

The value of the amount of writing, as the present data show, is indicated by the percentage of weighting of the assignment in the final course grade. A total of 51 assignments indicate both required length and weighting, of which 47 are categorized under the seven more frequently used types of assignments (Table 7). The weighting of the assignment in the final course grade, which ranges from $8 \%$ to $100 \%$, seems to correspond to the length of writing. The heavier weighting suggests that writing tasks that require a greater length demand more cognitive skills (Hale et al., 1996). Since the present data do not contain information about all the writing assignments in a particular course, it would be useful in future research to find out the amount of writing in various courses at the graduate level.

Table 7.

Length and Weighting of Seven Types of Assignments

\begin{tabular}{lccc}
\hline Types of assignments & $\begin{array}{c}\text { With information of } \\
\text { length \& weighting }\end{array}$ & $\begin{array}{c}\text { Range of mini- } \\
\text { mum length }\end{array}$ & $\begin{array}{c}\text { Range of } \\
\text { weighting }\end{array}$ \\
\hline Literature review & 5 & $1,000-4,000$ & $30 \%-60 \%$ \\
Scholarly essay & 18 & $600-4000$ & $10 \%-80 \%$ \\
Proposal & 3 & $800-3600$ & $30 \%-40 \%$ \\
Case analysis & 1 & 100 & $10 \%$ \\
Project & 3 & $1,000-4,000$ & $25 \%-50 \%$ \\
Review & 7 & $250-1,500$ & $10 \%-70 \%$ \\
Summary \& Response & 10 & $250-1,000$ & $8 \%-40 \%$ \\
Total & 47 & & \\
\hline
\end{tabular}


We noted that certain writing tasks require a greater length and have, therefore, heavier weighting and vice versa. For example, case analysis and response paper seem to have the shortest minimum length (minimum of 100 and 400 words respectively) and the smallest percentage of weighting (minimum of $10 \%$ and $8 \%$ respectively). In contrast, literature review, scholarly essay, and project require more words (maximum of 4,000, 4,000 and 6,500 words respectively) with greater percentages of weighting (maximum of $60 \%, 80 \%$, and $60 \%$ respectively). For example, the case analysis in audiology and speech science requires 100 to 150 words and counts 10 points towards the final mark (ASAS14, Example 4, Appendix). In comparison, the scholarly essay in anthropology requires 20 to 25 pages and counts 30 percent of the final course grade (ARAN12, Example 5, Appendix).

Apart from length, requirements for content and drafts for feedback during the writing process are also specified for many of the writing assignments. Some also provide suggested topics and examples of good writing to guide the students. Table 8 summarizes this information for the seven more frequently used types of assignments:

Table 8.

Guidance of Seven Types of Assignments

\begin{tabular}{|c|c|c|c|c|c|}
\hline \multicolumn{2}{|c|}{ Assignment types } & \multirow{2}{*}{$\begin{array}{c}\text { Content } \\
10\end{array}$} & \multirow{2}{*}{$\begin{array}{c}\begin{array}{c}\text { Process- } \\
\text { oriented }\end{array} \\
7\end{array}$} & \multirow{2}{*}{$\begin{array}{l}\begin{array}{l}\text { Topics sug- } \\
\text { gested }\end{array} \\
3\end{array}$} & \multirow{2}{*}{$\begin{array}{c}\begin{array}{l}\text { Examples } \\
\text { provided }\end{array} \\
1\end{array}$} \\
\hline $\begin{array}{l}\text { Library } \\
\text { research }\end{array}$ & $\begin{array}{l}\text { Literature review } \\
(\mathrm{n}=20)\end{array}$ & & & & \\
\hline & $\begin{array}{l}\text { Scholarly essay } \\
(n=29)\end{array}$ & 19 & 9 & 4 & o \\
\hline \multirow[t]{3}{*}{ Research } & $\begin{array}{l}\text { Proposal } \\
(\mathrm{n}=13)\end{array}$ & 8 & 6 & 2 & 1 \\
\hline & $\begin{array}{l}\text { Case analysis } \\
(\mathrm{n}=14)\end{array}$ & 5 & 4 & 1 & 1 \\
\hline & $\begin{array}{l}\text { Project } \\
(n=20)\end{array}$ & 8 & 8 & 4 & 2 \\
\hline \multirow[t]{2}{*}{$\begin{array}{l}\text { Evaluation \& } \\
\text { reflection }\end{array}$} & $\begin{array}{l}\text { Review } \\
(\mathrm{n}=15)\end{array}$ & 4 & $\mathrm{O}$ & o & $\mathrm{o}$ \\
\hline & $\begin{array}{l}\text { Summary \& Response } \\
(\mathrm{n}=22)\end{array}$ & 11 & 4 & 3 & 1 \\
\hline Total & $133(100 \%)$ & $65(49 \%)$ & 38 (29\%) & $17(13 \%)$ & $6(5 \%)$ \\
\hline
\end{tabular}

As Table 8 illustrates, about half of the seven types of assignments $(65=49 \%)$ specify content requirements (e.g., list of content expected). To guide students, some assignments also attach suggested topics $(17=13 \%)$ or an example of good writing $(6=5 \%)$. For example, a scholarly essay assignment on planning history in Community and Regional Planning contains a list of specific content requirements, including narratives about planning and planners, successes and failures of planning, dominant themes and voices, explicit or implicit theoretical frameworks, and the relevant intellectual and political projects (ASCR11, Example 6, Appendix). 
Table 8 also shows that about a third $(38=29 \%)$ of the assignments are process-oriented, providing feedback (either from peers or the teacher) on outlines or initial drafts before submitting the final product. As an example, a scholarly essay assignment from the English department requires students to revise drafts based on feedback before submitting their final paper (AREN21, Example 7, Appendix). The assignment requires students to submit "a near-complete draft of their final paper" to be peer reviewed. Each student writes a review of 500 to 750 words on two drafts written by their peers. With the feedback, students then meet in groups to talk about how to respond to the feedback and then submit "a brief report when they submit their final paper about how they have responded (or not, and if not why not) to the recommendations." It is interesting to note that students are asked to submit their reports to "the instructor as if the instructor was the editor of a scholarly journal." Again, students are encouraged to target their writing to the scholarly community beyond the classroom.

The two previous examples (ASCR11, AREN21) are instructor controlled with specific content and process control. Early research has also reported that some university assignments are instructor controlled with either explicit instructions (Canseco \& Byrd, 1989; Horowitz, 1986) or teacher feedback before final submission (Melzer, 2009). The present study suggests that peer feedback is also used to guide students in the writing process. In the present date, for example, review is a graded assignment that requires students to practice reviewing or evaluating others' or one's own work ( $37=26 \%$, Table 4$)$.

\section{Summary and Implications}

The present study, based on the analysis of 143 writing assignments from 90 graduate courses across faculties in a Canadian university, has identified nine types of writing tasks. Except for creative writing and exam, both of which have a low frequency (under 5), the other seven tasks are more frequently used, suggesting that many of these university assignments require doing library research or relying on source texts (literature review and scholarly essay), planning or conducting research to analyze data or case scenarios (proposal, case analysis, and project), and evaluating and reflecting on one's own or another's work (review and summary and response). The present data suggests that scholarly essay has the highest frequency, followed by summary and response. Comparisons of the seven more frequently used types of tasks across the four faculties where the majority of data were collected (arts, education, applied sciences, and medicine) illustrate different tendencies between the faculties of education and arts and the faculties of applied sciences and medicine. The former tend to assign more scholarly essays, whereas the latter tend to have more case analysis. While similar findings may have been reported in previous research, it is difficult to compare the findings as the same tasks may have been given different names, or different tasks the same names, in different studies.

Although the study is based on a small proportion of assignments at the participating university, analyses of the 143 writing assignments from 90 courses in the present study do generate some useful information for better writing instruction. First of all, the nine task types identified uncover a range of university-wide writing genres in use for both students and writing program instructors. This is also useful information for material developers as there are few academic writing textbooks available in the market that focus on disciplinary writing (Tribble, 2009). In addition, the shared requirements for research 
data or references and writing for academic and professional audiences suggest key writing skills that should be taught or practiced in EAP or graduate writing programs.

Apart from the range of task types, the distribution of the writing tasks across disciplines found in the present study is helpful for instructors teaching within or across disciplines. Faculty members need to know whether the writing tasks they assign concur with the practice of other instructors in the discipline and in what ways these assignments differ from those in other disciplines. According to Gardner and Nesi (2013), knowledge of the task types helps instructors explain the requirements for individual tasks. If students preparing for undergraduate programs can focus on practicing general writing tasks (Spack, 1988), those preparing for graduate programs, as the present study suggests, should benefit from interpreting and responding to specific task requirements assigned in graduate courses. The frequency distributions of the assignments in the present study suggest that certain writing tasks might be pertinent to certain disciplines that typically teach students to make meaning in their disciplinary ways. Following Casanave and Hubbard (1992), who note that graduate students of different disciplines need different kinds of help with writing, we suggest that students preparing for graduate studies also need specific help to prepare for graduate writing.

Finally, our study has implications for faculty members when assigning writing tasks. Professors need be explicit about the details of the genre they require without assuming that their students are already familiar with the generic conventions of the task. Many participating instructors do provide detailed content expectations or guidance with feedback during the writing processes, but some do not. The intervening of the instructors during the writing process, as Melzer (2009) put it, is "the most encouraging pattern" (p. W257). Instructors should widen their scope to offer all kinds of guidance in the writing process. According to Bridgeman and Carlson (1984), each task type stimulates particular writing skills. The wide range of tasks suggests the challenges and needs of students in their graduate courses. Future research needs to find out how students benefit from detailed information and feedback when completing the assignments because instructors need to be informed of the best practices to help their students to succeed. Course instructors could use examples of good student writing to analyze the genre and guide students in practicing disciplinary writing.

If students, especially graduate students, are required to write in their disciplines at the university level, researchers need to explore the construction and types of these writing assignments. Differing from theses and dissertations, writing assignments are opaque in structure because, as Loudermilk (2007) points out, they are designed and read only by individual course instructors. Building on research studies conducted in other countries, the present study invites more research as it has only scratched the surface of our understanding of the types and construction of writing tasks at the graduate level in the Canadian context.

\section{Acknowledgements}

This research is supported by UBC internal funding granted to the first author. We thank the instructors who were willing to share their course handouts and/or syllabi, Rae Lin who assisted in data collection, and the three anonymous reviewers who provided valuable feedback on an earlier draft of the paper. 


\section{References}

Braine, G. (1989). Writing in science and technology: An analysis of assignments from ten undergraduate courses. English for Specific Purposes, 8, 3-15. doi:10.1016/08894906(89)90003-3

Bridgeman, B., \& Carlson, S. B. (1984). Survey of academic writing tasks. Written Communication, 1, 247-280. doi:10.1177/0741088384001002004

Canseco, G., \& Byrd, P. (1989). Writing required in graduate courses in business administration. TESOL Quarterly, 23, 305-316. doi: 10.2307/3587338

Casanave, C. P., \& Hubbard, P. (1992). The writing assignments and writing problems of doctoral students: Faculty perceptions, pedagogical issues, and needed research. English for Specific Purposes, 11, 33-49. doi:10.1016/0889-4906(92)90005-U

Cooper, A., \& Bikowski, D. (2007). Writing at the graduate level: What tasks do professors actually require? Journal of English for Academic Purposes, 6, 206-221. doi:10.1016/j.jeap.2007.09.008

Gardner, S., \& Nesi, H. (2013). A classification of genre families in university student writing. Applied Linguistics, 34, 25-52. doi: 10.1093/applin/ams024

Hale, G., Taylor, C., Bridgeman, B., Carson, J., Kroll, B., \& Kantor, R. (1996). A study of writing tasks assigned in academic degree programs. Educational Testing Service Research Report 54. Princeton, NJ: Educational Testing Service.

Horowitz, D. M. (1986). What professors actually require: Academic tasks for the ESL classroom. TESOL Quarterly, 20, 445-460. doi: 10.2307/3586294

Loudermilk, B. C, (2007). Occluded academic genres: an analysis of the MBA thought essay. Journal of English for Academic Purposes, 6, 190-205. doi:10.1016/j. jeap.2007.07.001

Melzer, D. (2009). Writing assignments across the curriculum: A national study of college writing. College Composition and Communication, 61(2), W240-261.

Moore, T., \& Morton, J. (2005). Dimensions of difference: A comparison of university writing and IELTS writing. Journal of English for Academic Purposes, 4(1), 43-66. doi:10.1016/j.jeap.2004.02.001

Prior, P. A. (1998). Writing/Disciplinarity: A sociohistoric account of literate activity in the academy. Mahwah, NJ: Lawrence Erlbaum Associates.

Spack, R. (1988). Initiating students into the academic discourse community: How far should we go? TESOL Quarterly, 22, 29-51. doi: 10.2307/3587060

Tribble, C. (2009). Writing academic English-a survey review of current published resources. ELT Journal, 63, 400-417. doi:10.1093/elt/ccpo73

Zhu, W. (2004). Writing in business courses: An analysis of assignment types, their characteristics, and required skills. English for Specific Purposes, 23, 111-135. doi:10.1016/ So889-4906(02)00046-7 


\section{Contact Information}

Ling Shi

Department of Language and Literacy

Faculty of Education

University of British Columbia

ling.shi@ubc.ca

Ling Shi is a professor in the Department of Language and Literacy Education at the University of British Columbia. Her research focuses on second language writing, citations in academic writing, and teaching English as a second/foreign Language. She has published her research in journals such as Applied Linguistics, Journal of Second Language Writing, Research in the Teaching of English, Written Communication, and English for Specific Purposes.

Yanning Dong holds a PhD from the Faculty of Education at the University of British Columbia. Her research interests include teaching English as a second language, second language writing, higher education, and web-based learning. Her PhD research investigates the approaches to teaching critical thinking in second language writing. 


\section{Appendix}

\section{Examples of writing assignments}

\section{Example 1. A Scholarly Essay in History/Arts (ARHI13)}

For the major paper (historiographical essay), which should be in the range of 20-25 pages [double-spaced, regular font], you are asked to explore critically (highlight original) a representative body of material on one theme that has emerged from our work in [the course]. The assignment requires that you offer some understanding of the historiographical context of the theme being explored as well as identify theoretical and methodological influences that have shaped the literature that you are exploring.

\section{Example 2. A Case Analysis in Family Practice/Medicine (MEFP11)}

You are in your first year of practice. You attended a home birth for a woman having her second baby. Mrs D had given birth previously to a baby boy weighing $3900 \mathrm{~kg}$. There were no complications. During this past pregnancy there were no complications. Fundal height measurements were consistently 3-4 cms above gestational age. Labour started spontaneously. Contractions were regular. On abdominal palpation the fetus was longitudinal lie, cephalic presentation, left occipito transverse. After a labour of $7 \mathrm{hrs}$ first stage and 2 hrs second stage Baby D was born to the neck and then turtling became apparent. You started the shoulder dystocia protocol and internal procedures were required to release the left anterior shoulder. After birth Baby D's Apgars were 4 at 1 minute. He required bag and mask resuscitation but his heart beat was 100 and recovered to 140 bpm. He responded well and at 5 minutes his Apgars were 8. You transferred for paediatric assessment.

Erb's palsy of the right shoulder was diagnosed and did not resolve with physiotherapy. Eight months later you are notified that legal proceedings have been started and it is claimed that the Erb's palsy was caused by excessive traction during management of the shoulder dystocia.

In preparation for meeting with your legal representative you reflect on your care. What are the issues you would consider? What does the Midwives Protection Program offer which may help you or could have prepared you for the next steps in this case? What are your options with respect to communication and resolution with the family? How will you discuss this with your practice partners and colleagues? What is the evidence around the etiology of birth related Erb's palsy? Describe the evidence basis for shoulder dystocia management including: the frequency of occurrence, risk/benefit for management options, range of prognosis and sequelae, and your rationale for specific steps to follow in such cases.

\section{Example 3. A Case Analysis in Population and Public Health (MEPP21)}

The following scenario is entirely hypothetical.

There have recently been isolated reports from residents of the Township of Langley that there are gasoline odours coming from their water. At first these complaints came from residents who had private wells on their own property, and initial analyses of a cou- 
ple of water samples were unable to detect any traces of the constituents of gasoline. More recently, calls have been received from residents served by small "public" water systems, where up to 100 residences may be served by a single well. The water quality of these systems is under the jurisdiction of the local Health Authority. One tap-water sample taken has verified the suspicion: octane and other straight chain hydrocarbons were detected in the sample. You can download a map of Langley, indicating the sites of the complaints.

The Health Authority immediately issued an advisory to all residents in the vicinity of the calls to immediately stop using their water and has made arrangements for water to be trucked in.

They are now trying to prepare a short- and long-term response to this situation, and have asked for bids to conduct an exposure assessment with the following objectives:

- To determine the extent of contamination of the water supplies and whether the Guidelines for Canadian Drinking Water Quality have been exceeded, using the minimum number of samples for statistical validity

- To identify the sources and other factors affecting the presence of gasoline in the water supplies

- To develop plans to control the exposure based on the data collected in steps a. and b.

Please prepare a bid for this job to the Health Authority, with the following details:

- your sampling strategy (discuss all "elements" listed on page 2 of the sampling strategies notes)

- your method of determining the sources affecting exposure levels

- your method for determining compliance (please illustrate this with an example)

- your method of developing a control plan from the data, a cost estimate for the work. Prices should include taxes, travel time, travel costs, etc.

- a description of the technical expertise and experience of your company in the area of environmental hygiene

- a maximum one-page executive summary

Please remember that although this Request for Proposal asks for "statistical validity," the Health Authority will also be very interested in the bottom line.

You are welcome to talk to anyone you choose about this scenario. You may find helpful information about locations of gasoline stations, Township of Langley ground water, and Guidelines for Canadian Drinking Water Quality on the web.

\section{Example 4. Length and Weighting of a Case Analysis in Audiology and Speech Science (ASAS14)}

Course DVD sets are available on a sign-out basis. Comment on one of them for your discipline (Discussion sites provided on Vista for the DVD topics). These include interviews with practitioners and case scenarios with Aboriginal and non-Aboriginal actors. A set of questions goes with the scenarios, which will be posted under Course Content on Vista. 100-150 words. 10 points. 


\section{Example 5. Length and Weighting of a Scholarly Essay in Anthropology (ARAN12)}

This major assignment is a focused paper on a theoretical or methodological issue in archaeology that examines one of the topics that we've dealt with in this course and that you would like to explore in greater detail. The one key requirement is that it includes some actual analysis of archaeological data, from your own work or from published sources. This may include data that you are interested in examining as part of your dissertation or thesis research. One part of this assignment will include a detailed outline (2-3 pages) and a proposed bibliography of source material (15\%). The bibliography should be annotated with a brief description of why the source is relevant (a few sentences only). The second part will be the finished paper (30\%). It should be about 20-25 pages (doublespaced, excluding references).

Example 6. A Scholarly Essay in Community and Regional Planning/Applied Sciences with Content Requirements (ASCR11)

Write a history paper to compare and contrast the understanding of planning history presented in the following two texts and explore why there are such strikingly different accounts of planning history:

This paper needs to address the following range of questions:

- What story or stories are being told about planning and planners? (for example, celebratory or heroic or catastrophic or what kind of stories?)

- Is there a dominant narrative (for example, the success or failure of planning, the heroic planner)?

- What are the dominant themes?

- What is the theoretical framework (explicit or implicit)?

- What is the intellectual and political project of the author/s?

- Is there a dominant voice? Whose voice is that?

\section{Example 7. A Scholarly Essay Assignment from the English Department That Requires Revisions Based on Feedback (AREN21)}

The students submit a near-complete draft of their final paper. Each student then writes a "reader's report" of 500-750 words on the two drafts [written by their peers] and submit their reports to the instructor as if the instructor was the editor of a scholarly journal [and] also to the student as advice on revision. ... The students meet outside of class in their groups once the reports have gone back to the authors to talk about whether they work, what to do, etc. ... Students submit a brief report when they submit their final paper about how they have responded (or not, and if not why not) to the recommendations of all three reports (one of them is from the instructor). 